\title{
Bodily Democracy and Development through Sport - towards Intercultural Recognition
}

\author{
Henning Eichberg
}

University of Southern Denmark

KEYWORDS

ABSTRACT

The theory of 'development', when applied to sports, remains an ambiguous and unclear reference. 'Development', like 'modernization', can be interpreted as Western sports exported to the Third World, as a neo-colonial 'brawn drain' of African athletes to the West, as evolutionism and 'individualization', none of which considers cultural diversity. This article analyses functionalist developmental theory, currently mainstream in countries like Germany. Developmental theory has a tendency to overlook diversity in sports and, more specifically, dynamics in popular sports and movement culture within different social contexts. There is nothing like 'the one sport', nor does 'the soccer game' exist alone in the rich world of football. Diversity in sports inspires differentiated views of democracy. How are different forms of democracy, especially in today's 'competitive state', implicated in sports? There is no reason to cultivate an attitude of betterknowing when facing the development of 'the others'. This limitation launches a humble start for sports development as a means of mutual exchange and enrichment.

body, democracy, sport, intercultural recognition

\section{A German trainer and a young African soccer player - the Pygmalion effect}

"One can systematically comb one continent after another to help our friends in whatever country down the road, to reach the top in the soccer world. That is our goal. And it is our mission to ensure that they reach it."

This is what the German soccer trainer Dettmar Cramer (1978) stated in the West German Parliamentary journal "Das Parlament" when describing German soccer development to be applied to 'the others'. Cramer illustrated the vision through a story about his encounter with Saihon Sarr, a 16year-old, barefoot schoolboy from Gambia. Cramer discovered the boy in 1968 in Gambia's capital. In 1977, Cramer visited Norway to research the Mjøndal IF team, FC Bayern's opponent in the UEFAcup.

\footnotetext{
${ }^{1}$ Football trainer Cramer was one of the most profiled sports ambassadors and developmental legionaries of (West) Germany. After being close to being appointed as German Bundestrainer in 1964, he worked in 19671974 for FIFA and subsequently trained elite teams in USA, Saudi Arabia, Greece and Korea. With reference to his body size (only 1,65 m) he received the nickname "Napoleon of football".
} 
"I couldn't believe my eyes when I saw, in the midst of the home team, an African whose movements I recognized instantly. We shook hands after the game, not having seen each other in nine years. It was Saihon Sarr! He had accepted an offer from the Mjøndal team to play soccer and study sports in Oslo. He spoke fluent Norwegian and earned a salary working at a gas station. He was now 25 years old, married and was able to vacation in his homeland.

We spoke at length in Mjøndal, later in Munich, and after a revenge game in Oslo. We became friends - we used to say in a humorous yet sincere way 'Making friends is even more important than scoring a goal'. One thing I do know is that I will miss the many unforgettable experiences I had on the sidelines of the playing field in 70 countries around the world."

This example illustrates a mix of personal smugness and well-intentioned sports export ideas, i.e. to do sports means being discovered, emigrating to a better life, and making friends. Indeed, the trainer expresses certain sensitivity for the world's poor when recalling that in Gambia, "the players are poor and only the best amongst them go abroad." However, if this is said with a complaining undertone, it is rather an expression of personal sentiment. The solution demands that the individual leave his society and go out into the world.

There was no real interest in the Gambian people profiting from sports. If cultural conflict and the neocolonial dimensions of sport are overlooked, something is advocated which, in analogy to the brain drain of educational and intellectual professional emigration, is called a brawn drain in sports (Bale 1991).

Instead of seeing sports as a cultural effort, focus centers solely on the individual's quest to reach the top as its primary driving force. That recalls the story of Pygmalion, the sculptor from Ancient Greek mythology who sculpted a statue and fell in love with his self-imaged creation. Sports export (and more particularly combing for talent) and the Pygmalion effect are tied to the culture of Western individualism, of searching out and promoting individual talent in order to increase the athlete's market value. This individualized performance is practiced with no consideration given to the relationship between cultural identity and alienation. Elite sports and its global market form an arena in which the social promotion of individualization occurs.

\section{Bodily democracy}

The Cramer-Sarr case tells about democracy by the paradox that the author does not. Understanding this contradiction requires an insight into the relationship between sports and democracy. The democratic dimension of sports is not limited to the organizational level, where there may be formal self-determination and procedures of decision-making, i.e. it is not only about sports and politics. Democracy is implicated in sports at the practice level as well, in bodily selfdetermination and community, i.e. sports as politics.

Thus, the question rises how sports can contribute on a more basic level to the general theory of democracy where inherent linguistic double meanings are taken seriously, as in Danish folke-styre, German Volks-herrschaft, and English 'demo-cracy'.

The term 'democracy', derived from Greek demokratia, contains two components:

- Kratia means the organization of power and representation of the people - democracy's topdown approach. Democracy happens 'there' and is delegated from 'us here below' to 'those up there' (in parliament, government etc.).

- Demos means the people's actions and autonomy, democracy's bottom-up approach. This approach found its expression in the maxim of modern democracy: "We are the people!" which has been expressed again and again by democratic movements and democratic revolutionaries over 200 years. 
The understanding of popular democracy (as a bottom-up movement) meets with the understanding of a sportive movement as being something like 'bodily democracy'. This implies that democracy is more than just speeches, ideas and decisions - that democracy has its roots in the common practice of bodily movement and self-determination. Sports are a markedly noticeable field where the bodily practice dimension of democracy is expressed.

However, it is not only democratic qualities like self-determination, mutual recognition and people's empowerment that are found in sports, but opposite trends exist as well that tend to threaten active democracy. Expert domination in specific sport forms as well as authoritarian structures with their pyramid formation and top-down discipline has been well liked by a variety of dictatorships throughout history.

Fascist or communistic regimes are not mandatory for democratic diversity in sports to be threatened. It is also possible within a good democratic environment for sports to be threatened by non-democratic patterns. This is where we can turn to functionalism, evolutionism and unitary organization.

\section{Sports in the functionalist developmental theory - the values of sports export}

International mainstream thinking of sport development is reflected in a book about West German sociology of sports written by Helmut Digel (1989) about sports in developmental theory. Digel, a prior handball player and later foreman of the German Athletic Association, provided a checklist to theoretically ensure, evaluate and prove the value of sports development in other parts of the world. Why was sports export good for "the others"? Because sports had six central politically developmental 'functions'. According to this functionalist theory, sports served as:

- an instrument for personal development;

- a tool for integration, stimulating nation-building;

- an instrument providing identification;

- a tool for health policy;

- an instrument for ensuring equal opportunity; and

- a tool to satisfy peoples' basic needs.

Digel also mentioned five further functions as being important: Sport as

- an aid to education;

- an instrument to make social structures dynamic (institution building);

- a tool for economic and foreign policy (tourism, labor market);

- a tool for intercultural understanding; and

- an instrument for women's emancipation.

Common to Cramer's more individual case, and Digel's more comprehensive socialfunctionalist theory, were limitations to democracy.

The basis for this theory of sociological development was monopolistic unitary sports. It was sport as such, that represented the named values, not a multiplicity of sports cultures. This implied the existence of one single type of sport that was centrally defined, did not require pluralistic democratic discussion, and did not demand complex processes of intercultural recognition. As such, the theory reflected a unitary organization which in German sports was established in 1933, when the Nazis unified the diverse sports associations into one single federation which, under changing political conditions, was continued after 1945 both in West Germany and in the GDR.

The monopolistic logic of unitary sports became visible when Digel's theory took a polemic turn. Developmental theory violently opposed the support of popular movement cultures, traditional games, etc., which during the 1980s had actively been debated in West German sports developmental politics (Grupe 1985, Dietrich et al. 1986). Digel's developmental theory condemned this new 
orientation and characterized games from Africa, Asian and Latin America as being just marginally acceptable and not at all "real sports". These games should be regarded as folkloric like finger-pulling competitions in the Bavarian Alps. They simply lacked the necessary developmental 'functions'.

At this point, the concept of monopolistic sport aligned with the concept of functionalism, i.e. with a methodological concept from mainstream sociology, from structural-functionalism and system theory. The term 'function' is used in a broad and diffuse sense, including anything from Wesen (essence, nature) and 'inner essence', to intention, goal, instrumental benefit, utility, purpose, reason and meaning, and further to cause and driving force on the one hand, and to values, the correct and the good on the other. All of this happens oblivious to any ambiguity found in the term 'function', but rather with the good conscience of understanding 'function' as an expression of the 'objective' truth and with a tinge of quasi-mathematical flair. While Wesen is a comprehensive concept and, as such, open to controversial debate ("note that the phenomenon has a totally different Wesen"), 'function' is an explanatory term that refers to an objective causality ("if A, then B"). Norbert Elias (1970, pp. 8081 and pp. 137-38) once characterized 'function' as being "a hidden concept of causality".

The 'functional' of functionalist theory also has a reverse, i.e. the 'dysfunctional'. As stated, popular and traditional games were weeded out and labeled as laughable, "folkloric", and dysfunctional for desired public education and for health promotion purposes. These criteria of exclusion can be seen as fundamentally undemocratic aspects of functionalism.

Monopolistic and functionalistic thinking interacted in this developmental theory with evolutionism, which provided the historic framework for the theory. Evolutionism assumes a one-track line from 'primitive' to 'modern' society, where 'we' are the highlight of 'the History' (in the singular sense). As the 'most developed', we are the rich, the powerful, the civilized, the sport-givers who dominate the poor, less civilized, partially medieval beings who need to develop further in order to reach our historically elevated status, including the benefit of Western high-level Olympic sport. Evolutionism, with its narrative of the one Modernization (in the singular sense), was a project of neocolonial education (Leclerc 1972) - ... there is but one way, and 'the others' must follow it. In the practice of sports policy, this thinking was applied as sports export - export from us as those who can and know, to them who cannot.

What is generally missing in this picture is democracy. Monopolistic thinking, in combination with functionalism and evolutionism, are not just fertile ground for self-determination and recognition - which are basic components of democracy. It was the recognition of popular movement cultures in their plural forms, which functionalist development theory in the name of sports export opposed and was polemically turned against.

The functionalist theory of sports development is not just history. Although this theory was later nuanced, and expressed some self-critique, it held tight to its core belief: "Who promotes sport, promotes modernization" - both in the singular sense (Digel 1997, p. 237). Sport (especially athletics) promotes rationality, objectivity and quantification by competition, individualization and emotional control, connected with rules and bureaucracy, with the engineered progress and the technological productivity of sport results.

\section{Danish-Tanzanian cooperation - a contrasting case}

Danish sports create a contrast with monopolistic unitary sports, by practice, organization and ideology: Sport is not just one, but consists of diverse, often contrasting movement cultures (Elbæk 1996). This approach was adopted and expressed in, amongst others, the policy of Danish-Tanzanian sports development (Eichberg 2008b).

Tanzania, as a young, decolonized nation with peaceful socialist efforts over several decades, was a high priority country for developmental support, especially for the Nordic countries. Sports were included in Nordic support policies during the 1970s and '80s. However, developmental assistance in 
this field could assume many different forms. The West German sports assistance program, for example, involved sending elite trainers to Tanzania, just as to other African states. Chinese development projects consisted of building large cement stadiums to be used both for elite sports and for public state events. The Swedish model comprised collecting used sports equipment in the north and shipping it in containers to Dar Es-Salaam to promote the 'broad' dimension of sports. In contrast to these models, Danish assistance took the form of cultural cooperation at the local level. Soccer teams were launched amongst youth in socially burdened urban areas. The production of handmade balls and other sports equipment was also supported in the villages. Cooperation was initiated with rural local groups and institutions, which would resemble Danish associations, working with Ngoma dance, i.e. local traditions for singing, celebration and dance competitions (Larsen/Gormsen 1985).

There was also a dimension of discovery and knowledge-building implicit in this type of developmental cooperation. In order to support existing structures, one first had to know something about them. The Western 'expert' cannot just appear as 'better-knowing' but has to learn something; he or she had to discover other people's contexts, among these ethnic-cultural differentiations such as, for example, between the Sukuma and the Masaai. Another surprising effect surfaced: not only did Danes travel to Tanzania to assist by using the Danish experience, but Sukuma body culture became also a 'hit' in Denmark, giving African experiences a high status in the Nordic country. Tanzanian dancers and drummers traveled to Denmark, where an alternative youth movement developed around Ngoma, the so-called Utamaduni groups (Bischoff 1996). Utamaduni means 'culture' in Swahili - and it became an element of Danish youth culture. In this way, developmental cooperation turned into a type of cultural exchange, into cultural barter.

This cooperation had effects on both parts concerned. The 'giver' of support discovered something new from the 'receiver' of support, and not just the same as it was known before or in which Western expertise existed, like in the case of Cramer, the coach for 'world soccer' and the sociologist Digel, expert in the 'the functions of sport'. And for the 'receiver' of support, exchange became a source of identity work: See, we can do something that 'the rich' from the North cannot, but do appreciate.

There exists, thus, a connection between diversity in sports and the concept of development. The theory of sports' trialectical relations (Bøje/Eichberg 1994) developed in contrast to the perspective of unitary sport and functionalism. Trialectics mean that a distinction is made between

sport of achievement, where competition, ranking and results dominate,

sport of integration, having its roots in gymnastic exercise in rank and file, and setting focus on discipline, health education and fitness; and

popular movement culture, where people meet in bodily dialogue by festivity, games and dance.

Popular sports are, in this context, an empirical practice rather than an ideological construct as they are often thought of in the Danish context (Madsen 2003). Popular movement cultures are whether one speaks of Tanzanian ngoma, Danish mass gymnastics or the parkour of street culture about diversity that often is overseen in sports' theories and cultural policy. Popular grassroots sports (folkelig idrcet) are not quite identical with the "broad sport" (breddeidrcet) which is often perceived as the 'lowest' level of the pyramid of achievement. Popular movement culture is nothing 'less' measured by performance - but is practically and structurally different from 'the sport'. Popular sports also comprise old and new games, dance, outdoor life and people's festivities (Eichberg et al. 2007). This cultural breadth makes the concept of cultural movement both useful and flexible when meeting developmental challenges in other countries.

\section{Popular forms of football - the overlooked people's sport}

Body and movement culture is a search term that expands beyond the fields of traditional games and dance. Neither is it limited to what in functionalist theory is labeled as 'folkloric' and excluded 
from the accepted world of 'functionality' and its values to be supported. Popular sports may also comprise parts of mainstream sport.

Football is an example. International and Olympic organizations - FIFA, UEFA, IOC - have drawn on the formalized competitive game of soccer in order to legitimate their claims for political representation in the field of sport (Arnaut 2006). On closer inspection, however, football is much more than a unitary activity to be described in terms of standardized regulations, defined by the established organizational hierarchy of sport. Football is a rich world of popular, autonomous forms of practice that through their diversity, make a case for why soccer has become the world's number one sport, unlike, for example, handball. Here, a few forms from the rich world of football shall be named $^{2}$.

Street football is a broad phenomenon practiced mostly by young boys in urban milieus. It is neither linked to the formal pyramid of achievement sport nor to a standardized space. With the expansion of automobilism, the playing field in the street has been taken from street football. However, public initiatives in the spirit of welfare society try to support street football by establishing simple facilities and mini-pitches in urban environments.

People's football on the basis of pub teams has been the basis of workers' football as a distinctive popular practice in the twentieth century. This has been described in details in the cases of the German Ruhr district and the café culture of Vienna. Some of the original pub teams have later developed towards professional sport, as it was the case with Schalke 04, one of the German professional top teams. However, the majority of the local teams have not pursued that path.

Children's football has been passed as informal practice from generation to generation. This is what is played 'just around the corner'. Also this field of practice was endangered or expelled by the traffic power of the automobile. The main action of children's football is shooting against a defined 'goal', which may be a garage door or something similar. Goal shooting is characteristic for traditional games and dominated the popular culture of play before modern sport. It is, however, not at all harmless but can be marked by a sharp gender unbalance, boys keeping girls at distance.

Circle football is another form of popular football, often practised in urban parks. In this game, people form a circle and play the ball - often a light rattan ball - to each other, for enjoyment. The game can develop high skill and acrobatic dexterity, but it is non-competitive.

Hacky sack is a game that develops the acrobatic potentials of football, reminding of circle football. Here, however, it is not so much the play in group, but individual display that matters. Hacky sack had its up and down in popular practice and is nowadays shown off mainly in urban pedestrian areas.

Beach football has developed as a popular activity of its own character, in coastal environments, and different from soccer by more than the sanded ground. It is mostly practiced in touristic context, on par with beach volleyball. Tendencies can be registered to streamline this as a sport, parallel to beach volleyball, and during the 1990s, Beach Soccer Worldwide began to organize tournaments in partnership with FIFA and UEFA. However, it is still the vast majority of players who practice beach football as non-formal popular practice outside the formal pyramid of competitions.

Festive party football is often played by children together with parents in events such as school festivities, birthday parties or local neighbourhood gatherings, using a variation of mainstream football. But this popular form, which is typically integrated into festivities, is characterized by the absence of strict rules, of strict limitations in space and time, and by fluctuating participation on both sides. Though the competitive engagement may be high, it is not the result that counts, but togetherness in encounter. If the result is counted at all, it will be forgotten soon after the event. This is what in Danish is not called 'sport' or 'competition', but rather dyst, which is a match or bout where the result does not matter, but emotion is invested.

\footnotetext{
${ }^{2}$ For detailed sources see Eichberg, 2008a.
} 
Pause football is played at school, during free periods and breaks between classes. Also in this case, gender frequently determines the game. Often it is only the boys who dominate the football field, but it is documented that girls like to play the game when sufficient space is offered for them.

Social grassroots football is played by people who wish to promote integration, peace and other social aims through play and festivity. This is actively practiced in Italy, where the game is supported especially by the Unione Italiana Sport Per Tutti (UISP). Grassroots football, with antiracial programs and low priority of records, is known in Norway, Germany and United Kingdom. Through fluctuating participation on both sides, matches may stretch over several hours while people come and go.

Similar local forms of football, though lacking a formal political program, are known from France. Here, people meet to self-organize their local football matches that happen outside of the competitive pyramid of soccer sports clubs.

Ethnic groups often assemble around football as a scene of cultural togetherness. Turkish clubs in Germany as well as Surinam football in the Netherlands follow a logic, which is not oriented towards the pyramid of records, but towards identity and festivity bonding cultural minorities.

While ethnic football stimulates 'bonding', i.e. creating a sense of belonging to a certain group, other forms tend to 'bridge' and interact between different groups. Football for peace and international reconciliation works with play-oriented patterns of games that bridge people who have suffered the traumatic experiences of civil war or ethnic conflict. Grassroots work around the Cross Cultures Project Association (CCPA) has proven successful in the Balkans and Caucasus.

Pedagogical football is oriented towards the quest of personal development and was developed as an alternative against competitive elite sport. It is practised as a form of social-bodily learning, not dominated by the production of results. As a way of "playing ball with your life at stake", pedagogical football is supported by among others the Danish Sport-for-all organisation DGI. The federation has also built up summer camps around this activity.

Sport in connection with the working place is popular in different parts of Europe. In Scandinavian countries, corporation sport has a long tradition, using football as a field of togetherness in 'enterprise culture'. Again, this type of activity is not connected with the UEFA pyramid.

Not least, traditional popular football merits mention. Seen from an historic perspective it was the forerunner of modern soccer and rugby and is actively played still in some parts of Europe, e.g. as La Soule in Brittany (France), Ashbourne Shrovetide Football in England, and Calzio in Florence (Italy). Games like these affirm local - urban or rural - identity and combine popular festivity and ritualistic get-togethers with popular culture and matches, again distanced from the professional soccer pyramid.

The contribution of football to local bonding and bridging of different cultural groups has proven a success in international exchange. In developmental collaboration between Denmark and Tanzania, football was used to bring social life to burdened urban neighborhoods, in parallel with ngoma that included song, festivity, drumming and dance competitions in the villages.

\section{6. "We are all winners" - "The other" in body cultural diversity}

The various popular forms of football have in common that they allow people through various forms of practice to work through their relationships with each other. The ball moves between 'me' and 'the other'. This relationship sheds some light on the differentiation between sport of achievement, sport of integration and popular sport; and it explains why this differentiation is relevant to democracy-oriented developmental efforts. From the question of democracy, an important criterion for sports development can be derived: Who is 'the other' in the sport and how do we deal with 'the other'? There are at least three options. 
Within the frame of competition, 'the other' can either be better or worse than oneself. A distance is created from the perspective of hierarchal logic. Otherness is constructed by the distinction between the winner and the loser.

Another option is to focus on equality as in the case of classic National Democratic gymnastics. However, if everyone were to be equal, 'the other' would easily be perceived as deviation from the norm. He or she should be corrected by normalizing intervention.

'The other' can also simply be met as 'the other'. This would call for recognition of the difference, i.e. of otherness, which cannot be reduced to one's own norm or hierarchy. 'The other' is appreciated as an enrichment of one's own normality.

The relationship with 'the other' shows therefore that there is practical depth in the threefold pattern. The trialectics of movement culture is not only about different organizational forms, but it expresses a difference of rationalities. Quite different forms of rationality structure the various practices of normalization and diversity, of recognition and non-recognition. It makes a difference whether an activity results in: "We have won!" (Or "We lost!") - or "we are all winners", because in the exchange between Danish associational sport and Tanzanian drum dance, "we" become richer on both cultural sides.

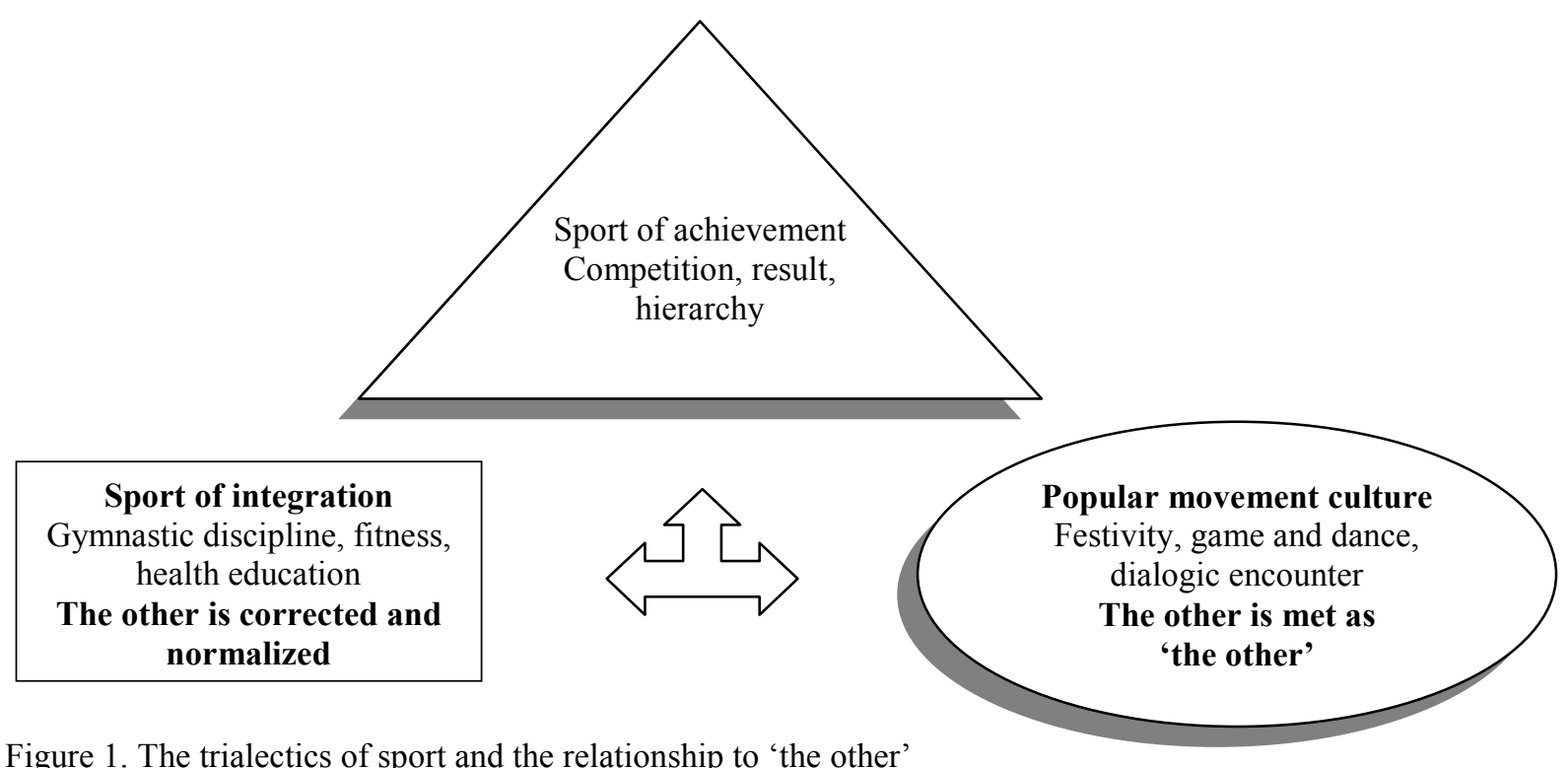

Figure 1. The trialectics of sport and the relationship to 'the other'

\section{Democratic diversity}

The internal contradictions of sports illustrate the diversity of democracy more generally - seen from a bottom-up perspective. Democracy has its roots not only in the ancient Greek city-state with its representative organization (which historically did not lead directly to modern Western democracy) but also in non-Western and pre-colonial forms of consensual democracy and self-organization in societies without chieftains and their formal power. Democracy has thus its preconditions in civil society rather than in governmental organization.

That is why democracy is no export article - just like sport is not. There is no point zero neither in sport nor in democracy.

Neither can Western NGOs nor Danish associations, therefore, be just 'the model' as such. However, they can help in exchange - and in educating oneself about one's own cultural position.

Not even the Danish people's academy (folkehøjskole) can be 'the model' for adult education around the world. Where the people's academy outside of Denmark and Europe was adopted as a source of inspiration and used in practice, this was done within the context of autochthonous, selfdetermined search processes. In India, Grundtvig was seen on par with Mahatma Gandhi and his 
political-spiritual revival, in Ghana and Nigeria in connection with African village democracy, and in Latin America on par with Paolo Freire's anticolonial educationalism. In Hungary, Grundtvig was compared with László Németh and the 'Hungarian way', while philosophers such as Martin Buber and Theodor Lessing in Germany adopted and practiced Grundtvigian education in connection with German youth movement and Jewish emancipation.

Similarly, the concept of bodily democracy - body, movement and popular sports as practice dimensions in active democracy - challenges the prevailing understanding of democracy. Do we really know what democracy is? Democracy is neither a given model nor a one-way street that goes from less to more democracy. In modern society one can distinguish between at least three different historical patterns that partially succeeded each other or partially questioned each other (Pedersen 2006a,b, Knudsen 2007) - and whose link to body culture still awaits closer clarification:

- Electional democracy striving towards the pursuit of political freedom (and legal equality)

- Social democracy striving towards social equality

- People's democracy striving from the grassroots level towards community and civil-societal practice.

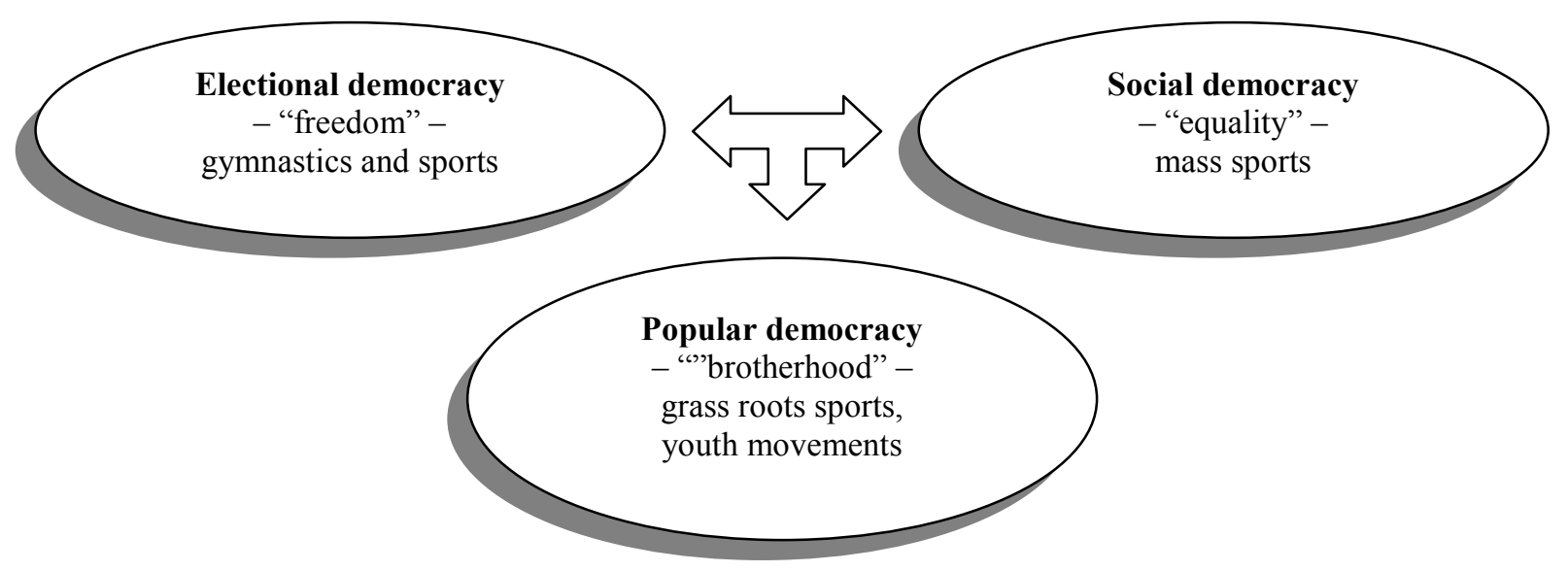

Figure 2. Trialectic relations of democratic visions

\section{State of law, welfare state, competitive state - and body culture}

The way of modern democracy through the last 200 years did not, however, just lineally unfold these democratic visions. And the dreams themselves were not harmoniously knit together, as the slogan and triad of the French Revolution, Liberté, Égalité, Fraternité - "Liberty, equality and brotherhood" - would suggest. Various types of systems and state developments emanated from them.

Electional democracy, which resulted from the 1789 revolution, led to the state of constitutional law, which in Denmark was built up from the 1840s. The liberal law-based state provided - inward the citizen with certain legal rights and - outward - built up the nation-state. At the same time, free industrial capitalism was let loose. And through formal schooling, people were disciplined towards citizenship and national identity.

In body culture, it was especially gymnastics that embodied this integration process. Gymnastics demonstrated community in rank and file, and self-discipline. Later, competitive sports entered the scene, primarily as a forum and instrument for national-state representation.

The new type of social democracy developed its dynamic striving after 1848 and resulted historically in the welfare state. In Denmark, it was implemented at the municipal level after 1900 and on a national level between the 1930s and 1950s. The distributive state, also called the compensatory or the solidarity state, was built on the basis of the labor movement and its quest for social rights. A new balance of distribution and consensus spread about people's equality. From being the owner of democratic rights, the tendency was now towards democratic engagement, participation and codetermination, towards self-activation, self-realization and solidarity developed on the basis of a 
certain interplay between the government and popular movements. Capitalism was regulated. And in the 1970s, welfare democracy got a facelift with educational reform that established people as cocitizens (medborger, not to be confused with the term borger, 'citizen').

In body culture, this welfare democracy had its base in sportive and gymnastic self-organization and in reform movements that flourished especially after 1900, and had relevant impact on the workers' cultural movement. Welfare municipalities and the national welfare state focused on laying out public parks, promoting tourism and 'people's holidays'. Mass sports emerged somewhere between public hygiene and 'people's enlightenment' and, from about 1970, became known as 'Sports for all'.

People's democracy surfaced during the 1800s co-op movement, in the world of associations and people's academies as well as in currents of grassroots democracy (often known as '1968'). They were in the 1960/70s often identified or associated with anti-colonial solidarity work directed towards the Third World.

In body culture, innovations took place in connection with hiking movements and youth movements, developing new types of outdoor activities, public festivities, grassroots gymnastics, sports tournaments, new games and dance. During the 1970s, on this basis, enthusiastic expectations were directed towards major social change from local community and civil society. But the third element of the democratic triad, 'fraternity', was never translated into an organized system. (Selfcritically: Eichberg 2009). However, it influenced the development of the welfare state - and not least the developmental cooperation in Africa, Asia and Latin America.

Instead of grassroots democracy, a new social formation of a different type became visible, called the competitive state (Pedersen 2006a,b, Knudsen 2007). It resulted as a consequence of the economic and political crisis of the welfare model in the 1980s/1990s, which led to certain demands of doing away with the welfare state and to replace it with the 'minimalist state' following Reagan's and Thatcher's model. This did, however, not happen since the welfare state - to the surprise of the 'stateminimalists' - succeeded by its competitive dynamics in the new global economy, by its flexible labor market, its national identity patterns and efficient demands for productivity. The welfare state was remodeled to become the competitive state. This new formation referred to a 'working society', which one also labeled as 'mobilizing society' or 'society of productivity'. In contrast to the classical welfare system, which focused on support to 'socially weak groups' and equal distribution of societal goods, the central point became now the mobilization of workforce. Under threat from so-called 'globalization', of international economic competition, there was given priority to work discipline and human resource management, mobility and flexibility, development of competences and professionalism. Democratic rights were now overshadowed by obligations, following the slogan of 'something for something'.

In body culture, the new societal formation is characterized by contradictory tendencies. An inner similarity can be seen between the competitive state and competitive sports. From the perspective of global competition, the state is implicated in new event sports, and municipalities and cities compete against each other to attract and showcase elite sports as 'lighthouses'. This has an equivalent on the personal level, where people currently are to be measured and evaluated for their achievement and competence. This is a sort of 'sportification' of state and society.

This mobilization has also a backside; it places stress on people's health and is limited - or followed up - by unwanted health conditions such as depression and obesity. This has led to initiatives of health promotion, 'exercise on prescription' and other exercise measures. The classic selforganization in local clubs tends to be outdistanced by an extensive setting-into-movement of the population through central sports campaigns and local project sport. 


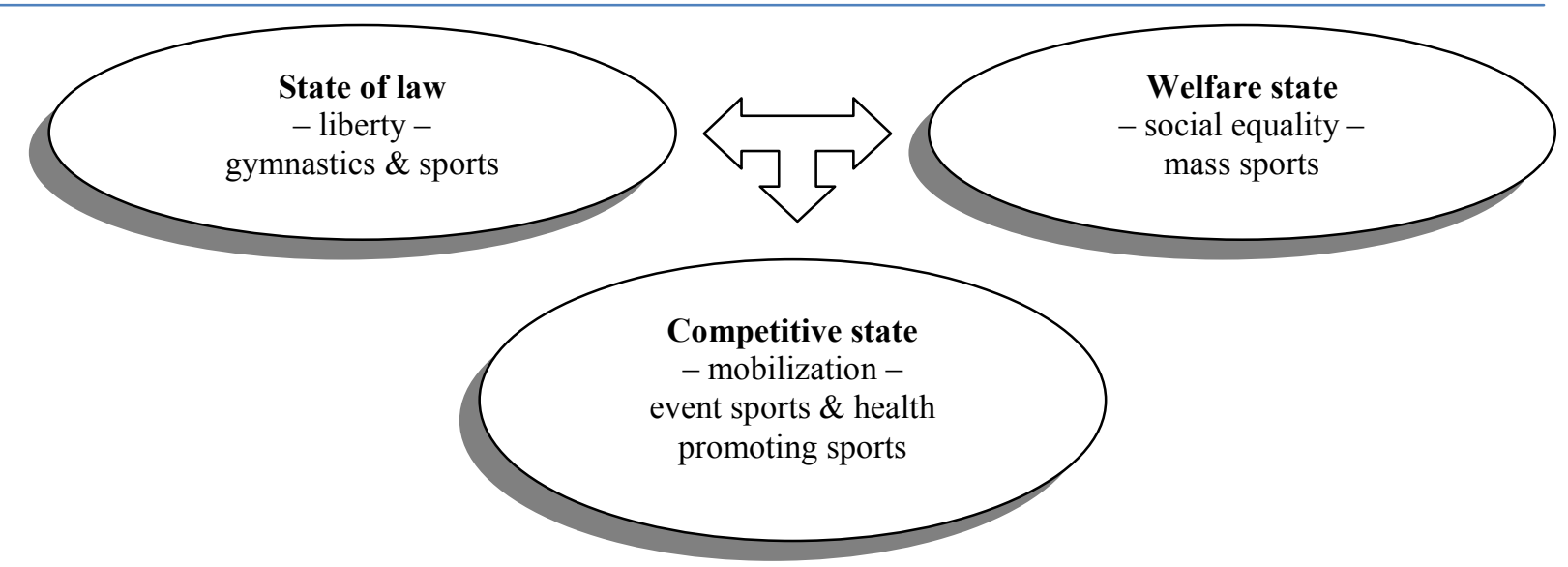

Figure 3. Tensions in democratic development

Whether the competitive state and the society of mobilization constitute a permanent new social formation, whether it is just a temporal hybrid, or whatever will follow after the competitive state - all this is yet unknown. However, no matter how the picture is framed, the societal structure has shifted, and body culture has transformed into something other than the linear 'development' of certain given 'functions'. 'Development' has become developments in the plural sense.

This insight is highly relevant to developmental work with other cultures. Since the transformation of our own society and our own sport remains far from clear, there is no reason for the West to meet 'the others' by a better-knowing attitude, neither as the functionalist sociologist, nor as the Pygmalion trainer did. If the diversity of democracy - as expressed by the contradictions of "freedom, equality, brotherhood" - means anything, it may be that we have to learn something especially about the third elements from 'the others'. We will never finish learning democracy - and never finish losing our democratic freedom and self-determination.

"We are the people!" - is a founding word of democracy. It is not just something people say people do it. Democracy is enacted and embodied. People have not, but do democracy - through common bodily and social movements.

\section{REFERENCES}

Arnaut, J. L. (2006). Independent European Sport Review 2006. Final version October 2006, pp. 175. http.//www.independentfootballreview.com.

Bale, J. (1991). The Brawn Drain. Foreign Student-Athletes in American Universities. Urbana, Chicago: University of Illinois Press.

Bischoff, M. (1996). Utamaduni-grupperne. In N. Elbæk et al. (Ed.) Krop, idrcet \& kultur (pp. 50-57). København: Mellemfolkeligt Samvirke \& DGI.

Bøje, C. \& Henning, E. (1994). Idrcettens tredje vej. Århus: Klim, 3. udg. 2000.

Cramer, D. (1978). Hilfe auf dem Weg zur Spitze. In Das Parlament, 28, 22, p. 9.

Dietrich, K. et al. (Ed.) (1986). Traditionelle Bewegungskultur und moderner Sport. Ansätze für die Entwicklungszusammenarbeit. Ahrensburg: Czwalina.

Digel, H. \& Peter, F. (1989). Sport in der Entwicklungszusammenarbeit. Köln: Weltforum.

Eichberg, H. (2004). The People of Democracy. Understanding Self-Determination on the Basis of Body and Movement. Århus: Klim.

Elbæk, N. et al. 1996 (red.). Krop, idrcet \& kultur. København: Mellemfolkeligt Samvirke \& DGI.

Elias, N. (1970). Was ist Soziologie? München: Juventa.

Gruppe, O. (Hrsg.) (1985). Sportwissenschaftliche Probleme und Konzepte der Entwicklungshilfe. Temahæfte af. Sportwissenschaft, 15, p. 3.

Knudsen, T. (2007). Fra folkestyre til markedsdemokrati. Dansk demokratihistorie efter 1973. København: Akademisk forlag. 
Kosiewicz, J. \& Obodyński, K. (Eds.) (2007). Sport for All as a Form of Education. Rzeszów: University of Rzeszów.

Larsen, N. \& Lisbet, G. (1985). Body Culture. A Monography of the Body Culture among the Sukuma in Tanzania. Vejle: DDGU.

Leclerc, G. (1972). Anthropologie et colonialisme. Paris: Fayard. - På tysk 1973. Anthropologie und Kolonialismus. München: Hanser.

Madsen, B. V. (2003). Oplysning i bevagelse. Kultur, krop og demokrati i den folkelige gymnastik. Århus: Klim. Pedersen, O. K. (2006a). Konkurrencestaten - velfærd på globale vilkår. In Tidsskriftet SALT, 15, 6, pp. 8-9.

(1997). Sport und Leichtathletik als Instrumente der Modernisierung in Entwicklungsländern. In H. Digel Probleme und Perspektiven der Sportentwicklung. Aachen: Meyer \& Meyer, pp. 233-246.

(2006b). Velfærdsrapporten som tidsbillede. Et essay om disciplinering og individualitet. Kritik, 38, 179, pp. 8799.

(2008a). Pyramid or democracy in sports? Alternative ways in European sports policies. In Idrottsforum, Malmö, 06.02.2008, http.//www.idrottsforum.org/articles/eichberg/eichberg080206.html

(2008b). From sport export to politics of recognition. Experiences from the cooperation between Denmark and Tanzania. European Journal for Sport and Society, 5, 1, pp. 7-32.

(2009). Mens vi venter på revolutionen... Om overraskelsens sociologi - en selvkritik. In Dominique Bouchet (Ed.). Forandringer af betydning for det danske samfunds fremtid. Ørbæk: Afveje, pp. 63-77.

AUTHOR'S ADDRESS: $\quad$ Henning Eichberg University of Southern Denmark Institute of Sport Science, Campusvej 55

DK-5230 Odense M, Denmark

Email: heichberg@health.sdu.dk 